кандидат педагогічних наук, старший викладач (Харківський національний університет імені В. Н. Каразіна)

\title{
ПІДГОТОВКА НАУКОВО-ПЕДАГОГІЧНИХ КАДРІВ В УНІВЕРСИТЕТАХ УКРАЇНИ ДРУГОЇ ПОЛОВИНИ ХІХ - ПОЧАТКУ ХХ СТОЛІТТЯ: СУЧАСНІ ІСТОРИКО-ПЕДАГОГІЧНІ ДОСЛІДЖЕННЯ
}

У статті узагальнено досвід сучасних науковиів щодо вивчення актуальних проблем підготовки науковопедагогічних кадрів в університетах України другої половини XIX - початку XX століття. 3'ясовано, що в сучасних історико-педагогічних прачях дослідників висвітлені питання законодавчого забезпечення роботи приват-доцентів, статусу приват-доцентів у різних університетах $і$ взаємини із професурою, кількісного складу приват-дочентів, прочедури зайняття посади приват-дочентів, наџіональної упередженості.

Ключові слова: науково-педагогічні кадри, приват-доцентура, pro venia legendi, дисертація.

Постановка проблеми в загальному вигляді. Вивчення досвіду розвитку системи вищої освіти України сприяє пошукові найбільш ефективних шляхів ії реформування на сучасному етапі. Крім цього, подальший розвиток університетської освіти не можливий без прогресивного, конкурентоспроможного професорсько-викладацького складу. Тому глибокий аналіз досягнень та недоліків досвіду процесу підготовки науково-педагогічних кадрів університетів України другої половини XIX - початку XX століття матиме вагомий внесок для подальшої модернізації вищої школи.

Аналіз останніх досліджень. Еволюцію науково-педагогічних кадрів в університетах України другої половини XIX - початку XX століття вивчали такі вчені, як П. С. Берзін, Н. В. Давидова, Н. М. Дем'яненко, А. П. Дмитренко, I. С. Даценко, Г. В. Додонова, З. І. Зайцева, Г. Касьянов, І. В. Костенко, О. Є. Іванов, І. І. Киричок, В. Г. Кремень, С. М. Куліш, Н. М. Левицька, О. Є. Музичко, С. І. Посохов, І. Ю. Регейло, Г. В. Самойленко, С. П. Стельмах, С. Г. Черняк, М. О. Шип та інші.

Мета статті - з'ясувати стан наукового висвітлення актуальних проблем підготовки науковопедагогічних кадрів в університетах України другої половини XIX - початку XX століття в сучасних історико-педагогічних дослідженнях.

Виклад основного матеріалу. У виданнях періоду 1950 р. - першої половини 1980-х рр. науковопедагогічна діяльність дореволюційних університетів України розглядалася украй однобоко. Максимальна увага приділялася подіям, пов'язаним зі студентськими хвилюваннями, опозиційними настроями частини викладацького корпусу. Постійно наголошувалося лише на тих соціальнопедагогічних та ідеолого-політичних факторах, що негативно впливали на розвиток професорськопедагогічних знань і вмінь. Майже не говорилося про наявність новаторських педагогічних ідей, заходів, які покращували організацію навчально-пізнавальної діяльності насамперед через зростання професійності викладацького корпусу. Що стосується виокремлення в роботах указаного періоду науково-педагогічного доробку приват-доцентів, то такий аналіз чи бодай згадування про цей інститут трапляються дуже рідко. Приміром, у брошурі "Одеський університет за 75 років (1865-1940)" (відповідальний редактор видання К. П. Добролюбський) взагалі не згадане поняття "приват-доцент".

Учені Київського університету підготували чергове видання, у якому охоплено науково-педагогічну діяльність професорсько-викладацького колективу за сто років. У ньому йшла мова й про наукові та педагогічні здобутки багатьох приват-доцентів: М. Є. Ващенка-Захарченка, В. П. Образцова, Ф. Г. Яновського, Є. В. Тарле, О. В. Леонтовича, В. Я. Желєзнова та ін. Автори відзначають бурхливе зростання корпусу приват-доцентів в Університеті Св. Володимира: якщо в 1884 р. їх налічувалося 16, то через десятиріччя - уже 40. Водночас говориться й про виразну нерівномірність їхньої чисельності на факультетах (більше половини з них працювали на медичному факультеті). Крім того, значна частина приват-доцентів на інших факультетах залишалася магістрантами, тобто вони склали усний магістерський іспит, однак не захистили дисертації [1: 45, 62-69]. Звичайно для цього були певні причини. Хоча в кінці XIX - на початку XX ст. на іспитах магістранту вже не задавали по $100-200$ й більше запитань, але обсяг знань, що він повинен був продемонструвати, залишався величезним. Наприклад, у Харківському університеті до $1917 \mathrm{p}$. більше ніж 10 років не відбувалося захисту дисертацій з російської історії на ступінь магістра чи доктора. Щоб скласти усний іспит (він проходив у два етапи), необхідно було опрацювати не менше 200-300 наукових праць. На іспиті були присутні, як правило, усі члени факультету, а продовжувався один іспит не менше 1,5-2 годин, інколи й довше.

У $1965-x$ р. 3'явилася узагальнювальна праця "Одеському університету сто років", у якій згадана та частина приват-доцентів, яка активно займалася науковою діяльністю: П. А. Спіро, Б. Ф. Веріго, 
В. П. Філатов, Р. О. Прендель С. М. Танатар, І. В. Петріашвілі, П. Г. Мелікішвілі, І. В. Слещинський, O. I. Томсон та інші. У роботі указувалося на хитке становище тих приват-доцентів, яких керівництво запідозрювало в нелояльності до чинної влади. Зокрема мова йшла про О. І. Маркевича, якого кілька років тримали на історико-філологічному факультетів без винагороди. Менше матеріалів щодо науковопедагогічної діяльності приват-доцентів у праці "Історія Одеського університету (1865-2000)" 2000 р.

Проблеми запровадження й розширення на загальнодержавному рівні інституту приват-доцентури торкнулася Г. І. Щетиніна. Зокрема, вона надала статистичні дані щодо чисельності приват-доцентури, указала на негативне ставлення професури до проекту міністрів народної освіти Д. А. Толстого та I. Д. Делянова, який повинен був сприяти подоланню труднощів у комплектуванні університетів досвідченими особами. Мова йшла про дозвіл директорам, інспекторам, викладачам класичних гімназій 3 університетською освітою претендувати на посаду приват-доцента з правом через три роки в разі захисту магістерської дисертації займати професорські вакансії [2: 115, 167-168].

Професор Т. М. Попова (Одеський університет) у 1998 р. підбила своєрідний підсумок у вивченні процесу актуалізації ролі інституту приват-доцентури в "повноправному навчальному функціонуванні університетів". Водночас вона підкреслила неможливість реалізації, згідно зі Статутом 1884 р., "вільної конкуренції" між штатними викладачами й приват-доцентами. Це було зумовлено, на їі думку, наявністю системи "обов'язкових" i "необов'язкових" курсів. Обмеження спецкурсів і неможливість вести обов'язкові навчальні предмети спричинили суттєву залежність приват-доцентів від сум гонорару, а ці суми, як правило, були невисокими, тому без стороннього заробітку частина приват-доцентів вижити не могла, підкреслює Т. М. Попова [3: 123-127].

У 2007 р. Т. М. Попова у монографію помістила невеликий розділ "О приват-доцентах". У ньому були повторені деякі матеріали їі попередньої статті 1998 р., а також підкреслено, що матеріально-фінансовий рівень основної маси приват-доцентів після 1884 р. залишався незадовільним, відзначено полегшення процедури зайняття цієї посади завдяки відміні розмірковування pro venia legendi.

Детальний аналіз статистичних даних про кількість приват-доцентів порівняно з екстраординарними й ординарними професорами Харківського університету здійснено в статті "Професорсько-викладацький корпус Харківського університету наприкінці XIX - на початку XX ст." вчених Г. О. Шарібжанової та С. М. Куліша. На підставі аналізу складених дослідниками таблиць можна побачити, що кількість приват-доцентів поступового збільшувалася. Крім цього, у дослідженні указано на ті розпорядження влади, які надавали приват-доцентам деякі пільги, наголошено, що не завжди приват-доценти досягали професорської посади, адже для отримання звання екстраординарного професора приват-доцентам фізико-математичного факультету в середньому, як писав Д. І. Багалій, потрібно було до 14 років, а для медиків - від 7 до 9 років. При цьому автори дійшли висновку, що в справі надання приват-доцентам штатних посад адміністрація університету мало зважала на позицію Міністерства народної освіти.

Проблему діяльності інституту приват-доцентури в університетах Російської імперії розглянула й I. С. Даценко. У своїх двох статтях ("Інститут приват-доцентів та підготовка молодих науковців в університетах Російської імперії (друга половина XIX - початок XX століття)", ("Інститут приватдоцентів у російських університетах XIX - початок XX століття") вона схарактеризувала процес запровадження інституту приват-доцентури, умови існування, різницю в правовому становищі доцентів $\mathrm{i}$ приват-доцентів. І. С. Даценко наводить численні приклади, що висвітлюють особливості запровадження приват-доцентури в різних університетах. Порушила дослідниця й питання дискримінації кандидатів на посаду приват-доцента через належність до "ненадійної" національності.

I. C. Даценко виокремила три групи приват-доцентів залежно від форми викладання (обов'язкові та необов'язкові курси) й оплати, але чомусь не назвала ще однієї групи - так званих "вічних приватдоцентів". Т. О. Сідорякіна дещо більш оптимістично оцінила становище приват-доцентів, зокрема тих, пробні лекції яких схвалювалися тим чи іншим факультетом. Вона стверджує, що після цього молоді викладачі відчували себе повноправними членами університетського середовища, ученими. До того ж після 1884 р. на приват-доцентів складали формулярні списки, як і на професорів, що було важливо для їхного соціального захисту [4].

Стаття М. В. Грибовського містить дані про причини різкого збільшення кількості приват-доцентів після вересня 1898 р. й висвітлює питання про те, чому в дещо кращому становищі були лише ті приватдоценти, які вели обов'язкові навчальні курси. У цілому, на думку науковця, заплановані владою цілі приват-доцентури в університетах Російської імперії повністю так і не були реалізовані [5].

О. Ю. Жарова коротко розглянула динаміку появи в університетах Російської імперії посади приватдоцента, починаючи з Дерптського університету, де ця посада фігурувала під назвою "доцент". Учена також детально висвітлила умови запровадження приват-доцентури згідно зі статутами 1863 та 1884 років й продовжила тему, згадувану іншими авторами, щодо викладання приват-доцентами тих курсів, для яких не були передбачені окремі кафедри [6]. 
Н. М. Левицька використала порівняльний метод, щоб виявити загальне й особливе в зростанні чисельності приват-доцентів в університетах Свропи та Російської імперії, простежити долю приватдоцентів у професорсько-викладацькому корпусі [7].

Процес запровадження в Харківському університеті приват-доцентури, зростання кількості викладачів на цих посадах, складні умови існування через нерегулярну винагороду висвітлено в статті C. М. Куліша "Інститут приват-доцентури в Харківському університеті другої половини XIX - початку XX ст.".

I. В. Піскунов проаналізував законодавчі статті, які з 1803 р. нормували діяльність приват-доцентів (хоча варто зауважити, що ця назва з'явилася офіційно дещо пізніше). Він звернув увагу на те, що до 8 березня 1865 р. приват-доценти надто рідко залучалися до інтенсивного викладання, що гальмувало збільшення їх кількості. Дослідник зауважив, наприклад, що в Університеті Св. Володимира в Києві в кінці 1860-х рр. через укорінену традицію балотувати всіх викладачів на засіданнях вченої ради приватдоцентура розвивалася недостатньо. Автор позитивно оцінив намагання міністра народної освіти Д. А. Толстого в напрямі більш масового запровадження приват-доцентури (мова йшла про рішення міністра заміщувати вакантну кафедру приват-доцентом не пізніше, ніж через півроку) [8: 100-105].

На суттєвій ролі приват-доцентів у навчальному процесі наголошено в монографії "Історія Київського університету". У дослідженні показано, що якщо в 1878 р. Університет Св. Володимира мав усього 10 приват-доцентів, які при цьому працювали за наймом, то на початку ХХ ст. ситуація склалася так, що без значної кількості цих "молодших викладачів" факультети не могли повноцінно функціонувати, у наслідок чого за 1914-1917 pp. на посаду приват-доцента було зараховано 45 осіб, у тому числі професорів М. О. Тихомандрицького та В. Устьянцева [9: 96, 190-196].

У біографічному довіднику 2014 р. "Професори Київського університету" з блоків інформації про службову діяльність частини професорів чомусь випала інформація про період їхнього перебування в приват-доцентурі. Мова йде про Є. І. Афанасьєва, Б. Я. Букреєва, П. В. Воронця, В. С. Іконникова, Й. Й. Косоногова, Ю. П. Лауденбаха, В. П. Образцова, О. М. Сєверцова та інших.

Колектив викладачів Одеського національного університету підготував працю "Одеський національний університет імені I. І. Мечникова. Історія та сучасність (1865-2015)", у якій відображена науково-педагогічна, просвітницька, виховна діяльність цього університету за 150 років. Зусиллями 156 авторів удалося досить глибоко й аргументовано висвітлити, причому персоніфіковано, роботу як кафедр університету, так і окремих викладачів. Подано також аналіз попередніх видань такого плану, їхні сильні та слабкі сторони. Уперше вказано, скільки приват-доцентів працювало в університеті в дореволюційний період - 300 (42 - на історико-філологічному, 101 - на фізико-математичному, 24 - на юридичному, 133 - на медичному факультетах). Доволі лаконічно розглянуто особливості педагогічної та наукової майстерності частини приват-доцентів, ставлення до них з боку професури та студентів. У дослідженні підкреслено, що частина приват-доцентів мала достатній рівень матеріально-фінансового забезпечення, хоча він і досягався тяжкою працею на кількох посадах за сумісництвом. У разі ж передчасної смерті, говориться в аналізованій праці, сім’я приват-доцента могла опинитися на межі жебрацтва.

Зв’язки із закордонними університетами глибоко досліджені в монографії "Університети України в міжнародних наукових зв'язках Російської імперії (друга половина XIX - початок XX ст.)" О. Іваненко. Ці зв'язки мали не лише суто ознайомчо-учнівський характер із боку викладачів університетів України, але й практичну користь. Так, ботанік, приват-доцент Я. Я. Вольц лише за 1863 р. одержав від восьми закордонних Ботанічних садів 2260 сортів насіння. Приват-доцент кафедри західноєвропейської літератури Є. В. Анічков не зміг би підготувати текст магістерської дисертації з історії пастушої поезії без вивчення стародруків XVI - XVII ст. і рукописів у бібліотеках Великобританії, Франції, Італії. Під час стажування приват-доценти могли оцінити ті чи інші педагогічні прийоми західних професорів, методики читання навчальних курсів. Щодо оцінки західної системи викладання, то у викладачів 3 України були свої міркування. Так, за словами Ф. Г. Міщенка, викладання палеографії найкраще було поставлене лише у Франції. І. В. Лучицький упевнився, що знання з історії у французьких студенів набагато міцніші, ніж у німецьких тощо.

Якщо про таких приват-доцентів, які стали професорами, як М. П. Драгоманов, В. С. Іконников, Л. С. Ценковський, М. Ф. Сумцов, М. Д. Пильчиков, М. П. Василенко, Є. М. Щепкін, О. І. Маркевич тощо, писали досить багато, то, наприклад, А. С. Вязігін, О. М. Деревицький, О. О. Козлов, М. К. Кульчицький, М. Й. Куплеваський, Д. І. Піхно, Є. М. Трубецькой, М. М. Цитович, П. П. Цитович та багато інших рідко привертали увагу. Якщо про них і згадували до кінця 80-х рр. ХХ ст., то в негативному плані або побіжно. Так професор-юрист М. Й. Куплеваський (ректор Харківського університету в 1901-1905рр.) був схарактеризований як "убогий блідий адміністратор і професор", що, зрозуміло ж, суперечило реальності.

Ще менше матеріалів є про тих приват-доцентів, які з об’єктивних чи суб'єктивних причин так і не отримали професорської кафедри. Про одного 3 них у статті 3 характерною назвою "Відомий незнайомець..." розповів Л. П. Чурілов. Мова йде про А.-Ф.-Ю. К. фон Зіверта, приват-доцента 
Університету Св. Володимира, який раніше швейцарця М. Картагенера виявив синдром зворотного розміщення внутрішніх органів у людини. Працюючи в Київському військовому госпіталі, фон Зіверт проводив досліди, які в наші дні іменують біомедичними. На IV Всеросійському конгресі терапевтів 1912 р. у Києві дослідник зробив справжню "революційну" доповідь щодо активних механізмів діастоли. На жаль, невідомою залишається навіть дата його смерті.

Із кінця XX - початку XXI ст. увага до опису життєвого шляху окремих персоналій (антропологізація науки) значно посилилася. Виходять друком дисертації, монографії та статті, що висвітлюють науковопедагогічну роботу факультетів, окремих кафедр. Однак і в наш час трапляється, що дослідники, характеризуючи діяльність професури, оминають здобутки "молодших викладачів". Скажімо, у статті "Географічні та геологічні науки в Одеському університеті: історія, сучасний стан, перспективи" одеських учених мова йде про таких приват-доцентів, як Р. О. Прендель, С. Г. Попруженко, Г. Я. Точидловський, О.В.Клосовський, В. Д. Ласкаров, Г. І. Танфільєв та інших, але без згадки про приват-доцентський етап у їхньому житті.

Рідкісним явищем можна назвати факт присвячення двох підпараграфів у докторській дисертації "Философия в Харьковском университете: история институций, трудов и персоналий (1804-1920)" В. О. Абашника діяльності приват-доцента І. С. Продана. Протягом 1906-1916 pp. І. С. Продан працював на кафедрі філософії Харківського університету як приват-доцент. Спроба науковця отримати в 1913 р. посаду екстраординарного професора виявилася невдалою через упереджене ставлення до його філософських концепцій з боку прихильників неокантіанства.

Сучасні науковці виділяють у Новоросійському університеті корпоративні угруповання "малоросів" i "москвичів". До останніх вони зараховують I. І. Мечникова, М. О. Умова, I. М. Сєченова, О. О. Ковалевського, Я. Я. Вальца та інших. "Малоросами" ж були начебто К. І. Коростельов, Є. Ф. Сабінін, Ф. І. Леонтович, Р. В. Орбінський та інші [10: 28-30].

Про існування "міжпартійних" угруповань в Університеті Св. Володимира, Харківському університеті теж є відповідні матеріали. Безумовно, що при вирішенні кадрових питань саме через упередження вибори того чи іншого кандидата на посаду приват-доцента або переведення на посаду екстраординарного професора (чи виконувача обов'язків) відбувалися 3 відчутною суб' єктивністю. Однією $з$ причин формування угруповань була національна, пов'язана 3 недовірою до викладачів польського та єврейського походження. Вона була характерною не лише для владних структур, але й для частини професури й навіть деяких приват-доцентів - прихильників "Союзу російського народу". Хоча найбільш гострою ця проблема була у Варшавському університеті, проте й у трьох університетах України теж спостерігалися її прояви.

Висновки та перспективи подальших досліджень. Таким чином, огляд сучасної історикопедагогічної літератури свідчить, що подальші дослідження ролі приват-доцентів Університету Св. Володимира, Новоросійського та Харківського університетів актуальні й доцільні не лише 3 пізнавальної позиції, але й з огляду на потребу актуалізації досвіду цього інституту для сучасності. Але сьогодні бракує наукових публікацій про процеси запровадження приват-доцентури у відповідних університетах, а ці процеси, як показують архівні джерела, були досить складними й мали свою специфіку в різних навчальних закладах.

Вивчення потребують причини частого вибору університетами не системи конкурсів, а системи персональних рекомендацій при заповненні вакансій, а також вивчення ролі попечителів навчальних округів, що призначали приват-доцентів.

\section{СПИСОК ВИКОРИСТАНИХ ДЖЕРЕЛ ТА ЛІТЕРАТУРИ}

1. Історія Київського університету. - К. : Вид-во Київського університету, 1959. - 629 с.

2. Щетинина Г. И. Университеты в России и Устав 1884 года / Г. И. Щетинина. - М. : Изд-во "Наука", 1976. $231 \mathrm{c}$.

3. Попова Т. Н. Институт приват-доцентства в университетах Российской империи (2-я пол. XIX - нач. XX вв.) / Т. Н. Попова // Записки історичного факультету Одеського університету. - 1998. - Вип. 7. - С. $122-130$.

4. Сидорякина Т. А. Процесс "вхождения в науку" молодого ученого : ритуал перехода в рамках "профессорской культуры" / Т. А. Сидорякина // Вестник Омского университета. - 2009. - № 3. - С. 88-94.

5. Грибовский М. В. Феномены приват-доцентуры в российских университетах конца XIX - начала XX вв. / М. В. Грибовский // Вестник Московского государственного обласного университета. Серия "История и политические науки". - 2012. - № 2. - С. 103-108.

6. Жарова Е. Ю. Проблемы молодых ученых : категории научно-педагогических работников в университетах Российской Империи ХІХ - начала ХХ вв. / Е. Ю. Жарова // Актуальные проблемы теории и практики. Гуманитарные науки (Брянск), - 2012. - № 3. - С. 18-22.

7. Левицька Н. М. Склад та соціально-правовий статус викладацького корпусу вищих гуманітарних закладів Наддніпрянщини (друга половина XIX - початок XX ст.) / Н. М. Левицька // Гілея : Науковий вісник : [зб. наук. праць]. - 2012. - Вип. 64. - С. 12-18. 
8. Пискунов И. В. Правовое положение приват-доцентов российских университетов (1803-1884) / И. В. Пискунов // Вестник православного Свято-Тихоновского гуманитарного университета. - Серия 2 : История Русской Православной Церкви. - 2014. - Вып. 4. - С. 98-116.

9. Історія Київського університету : [монографія] / [Верба І. В., Вербовий О. В., Горбань Т. Ю. та ін.] ; кер. авт. кол. В. Ф. Колесник. - К. : Видавн.-поліграф. центр "Київський університет", 2014. - 895 с.

10. Желясков С. А. Метрические книги Александро-Невской церкви Императорского Новороссийского университета как источник исследований его профессорско-преподавательского состава / С. А. Желясков, В. В. Левченко // Південний захід. Одесика. - 2011. - Вип. 11. - С. 22-34.

\section{REFERENCES (TRANSLATED \& TRANSLITERATED)}

1. Istoriia Kyivs'koho universytetu [The History of Kyiv University]. - K. : Vyd-vo Kyivs'koho universytetu, 1959. $629 \mathrm{~s}$.

2. Shchetinina G. I. Universitety v Rossii i Ustav 1884 goda [Universities in Russia and Statute of 1884] / G. I. Shchetinina. - M. : Izd-vo "Nauka", 1976. - $231 \mathrm{~s}$.

3. Popova T. V. Institut privat-dotsenstva v universitetakh Rossiis'koi imperii (2-ya pol. XIX - nach. XX vv.) [Institute of Privatdocents at Universities of Russian Empire (the 2-nd Half of the XIX - the Beginning of the XX Centuries)] / T. N. Popova // Zapysky istorychnoho fakul'tetu Odeskoho universytetu [Odessa National University Journal]. 1998. - Vyp. 7. - S. 122-130.

4. Sidoriakina T. A. Protsess "vkhozhdeniia $\mathrm{v}$ nauku" molodogo uchionogo : ritual perekhoda $\mathrm{v}$ ramkakh "professorskoi kul'tury" [The Process of "Entering the Science" of a Young Scientist : the Ritual of Transition Within the "Professorial Culture"] / T.A. Sidoriakina // Vestnik Omskogo universiteta [Omsk University Journal]. 2009. - № 3. - S. 88-94.

5. Gribovskii M. V. Fenomeny privat-dotsentury v rossiiskikh universitetakh kontsa XIX - nachala XX vv. [Privat Assistant Professorship Phenomena in Russian Universities at the End of the XIX - the Beginning of the XX Centuries] / M.V. Gribovskii // Vestnik Moskovskogo gosudarstvennogo oblastnogo universiteta. Seriya "Istoriya i politicheskie nauki" [Bulletin MSRU. History and Political Sciences]. - 2012. - № 2. - S. 103-108.

6. Zharova E. Yu. Problemy molodykh uchionykh : kategorii nauchno-pedagogicheskikh rabotnikov v universitetakh Rossiis'koi Imperii XIX - nachala XX vv. [Problems of Young Scientists : Categories of Scientific and Pedagogical Workers at Universities of Russian Empire the XIX - the Beginning of the XX Centuries] / E. Yu. Zharova // Aktual'nyie problemy teorii i praktiki. Gumanitarnyie nauki (Briansk) [Burning Problems of Theory and Practice. Liberal Arts]. - 2012. - № 3. - S. 18-22.

7. Levytska N. M. Sklad ta sotsial'no-pravovyi status vykladatskoho korpusu vyshchykh humanitarnykh zakladiv Naddniprianshchyny (druha polovyna XIX - pochatok XX st.) [The Staff and Social and Legal Status of Teaching Corps of the Higher Humanitarian Establishments of Naddniprianshchyna (the Second Half of the XIX - the Beginning of the XX Century)] / N. M. Levytska // Hileia. Naukovyi visnyk [Hileia. Journal] : [zb. nauk. prats]. 2012. - Vyp. 64. - S. 12-18.

8. Piskunov I. V. Pravovoie polozhenie privat-dotsentov rossiiskikh universitetov (1803-1884) [The Legal State of Privat Assistant Professors of Russian Universities (1803-1884)] / I. V. Piskunov // Vestnik pravoslavnogo SviatoTihonovskogo gumanitarnogo universiteta. Seriya 2 [Saint Tikhon's Orthodox University Journal]. - Istoriia Russkoi Pravoslavnoi Tserkvi. - 2014. - Vyp. 4. - S. 98-116.

9. Istoriia Kyivs'koho universytetu [The History of Kyiv University] : [monohrafiia] / [Verba I. V., Verbovyi O. V., Horban T. Yu. ta in.] / ker. avt. kol. V. F. Kolesnyk. - K. : Vydavn.-polihraf. tsentr "Kyivskyi universytet", 2014. $895 \mathrm{~s}$.

10. Zhelyaskov S. A. Metricheskie knigi Aleksandro-Nevskoi tserkvi Imperatorskogo Novorossiiskogo universiteta kak istochnik issledovanii yego professorsko-prepodavatel'skogo sostava [Registers of Alexander Nevsky Church of Imperial Novorossiisk University as the Source of the Research of Its Faculty] / S. A. Zheliaskov, V. V. Levchenko // Pivdennyi zakhid. Odesika. - 2011. - Vip. 11. - S. 22-34.

\section{Таможская И. В. Подготовка научно-педагогических кадров в университетах Украины второй} половины XIX-начала XX века: современные историко-педагогические исследования.

В статье обобщен опыт современных ученых по изучению актуальных проблем подготовки научнопедагогических кадров в университетах Украины второй половины ХІХ-начала ХХ века. Выяснено, что в современных историко-педагогических трудах исследователей освещеены вопросы законодательного обеспечения работы приват-доцентов, статуса приват-доцентов в различных университетах и взаимоотношения с профессурой, количественного состав приват-доцентов, проиедуры занятия должности приват-доцентов, начиональной предвзятости.

Ключевые слова: научно-педагогические кадры, приват-доцентура, pro venia legendi, диссертация.

\section{Tamozhska I. V. Scientific and Pedagogical Staff Training in Universities of Ukraine in the Second Half of the XIX - the Beginning of XX Century: Modern Historical and Pedagogical Researches.}

The experience of modern scholars, concerning the study of urgent problems of the scientific and pedagogical staff training in universities of Ukraine in the second half of XIX-beginning of XX century is generalized in the 
article. This in-depth analysis of the achievements and shortcomings of the experience of the process of preparation of scientific and pedagogical staff of the universities of the definite period has a significant contribution to the further modernization of the modern high school.

To the subject of our study of particular scientific interest are the works of such scholars as V. O. Abashnik,

I. S. Datsenko, O. Yu. Zharova, O. Ivanenko, S. M. Kulish, I. V. Piskunov, T. P. Popova, H. I. Shchetinina.

It is explored that in modern historical and pedagogical works of researchers the issue of the legislative support of private assistant professors, their status in different universities and the relationship with professors, the quantitative composition of private assistant professors, the procedure of receiving the post of private assistant professors, national bias are revealed.

It is defined that the scientists have not conducted in-depth and comprehensive analysis of technology of introduction of private assistant professorship at the St. Vladimir University, Novorossiysk and Kharkov Universities. The attention is focused on the fact that the authority of the scientific and pedagogical staff with higher scientific and academic degrees gradually increased at the universities, but all the reasons for such changes are not listed. The question of the ratio of essential and optional courses for private assistant professors is not sufficiently studied yet. Detailed analyses of private assistant professors' hourly workload and their rewards, so far as the level of their lives depended on this, are not conducted. It is found that what universities required were the frequent selection not competitions, but letters of recommendation when filling vacancies. It is observed that the role of guardians of educational districts who appointed private assistant professors is not clearly elucidated.

Therefore, the revealing of the process of implementation and rooting of the private assistant professorship system in the university life enables to make a conclusion about the necessity of the existence of this Institute. It is natural to take into consideration modern realities of private assistant professorship renewal.

Key words: scientific and pedagogical staff, private assistant professorship, pro venia legendi, dissertation. 